\title{
O trabalho das mulheres do Jequitinhonha: a atividade da cerâmica das viúvas de marido vivo
}

\author{
Gianne Maria Montedônio Chagastelles*
}

\section{Introdução}

Este estudo problematiza o trabalho na atividade da cerâmica de três artesãs das localidades de Coqueiro Campo (situado no município de Minas Novas) e de Campo Buriti (situado no município de Turmalina), integrantes do Vale do Jequitinhonha, em Minas Gerais, região pobre e seca do semiárido do norte de Minas. Para a cerâmica se configurar, é indispensável o reconhecimento por parte da comunidade, ou seja, o fato desta reconhecê-la como capaz e com valor. As condiçóes para isso se ligam à existência de elementos tradicionais da sociedade e da cultura. As ceramistas se consideram como praticantes de uma arte, não de um negócio, decorrendo disso, inclusive, formas diferenciadas de remuneraçáo. Essa arte se traduz como algo que circula como um bem e preenche as necessidades de sonho da comunidade. Destacam-se também as relaçóes entre as ceramistas e o público, correlação fundadora, pois é necessária para que as

Professora Adjunta de História da Arte e Artes Visuais da Universidade do Estado do Rio de Janeiro (UERJ). Doutora em História Social pelo Programa de Pós-Graduação em História Social (PPGHIS) do Instituto de História (IH), da UFRJ, com estágio sanduíche na Università IUAV di Venezia. Mestre em História e Crítica de Arte pelo Programa Pós-Graduação de Artes Visuais (PPGAV) da Escola de Belas Artes (EBA) da UFRJ. Bacharel em Pintura (EBA/UFRJ). Autora das seguintes obras: Alegoria na arte brasileira (1980-2000). Rio de Janeiro: Multifoco, 2013; Eternidade do efêmero: memória e vivência na arte brasileira dos anos 90 - Jarbas Lopes, Laura Lima e Cabelo. Rio de Janeiro: Multifoco, 2012. Organizadora dos livros: Ensaios de imagens: cidades. Rio de Janeiro: Multifoco, 2016; Ensaios de imagens: comunicação. Rio de Janeiro: Multifoco, 2017; Ensaios de imagens: deslocamentos. Rio de Janeiro: Multifoco, 2018; Ensaios de imagens: memória e patrimônio. Rio de Janeiro: Multifoco, 2019. E-mail: giannem@globo.com. 
ceramistas se configurem e realizem suas artes. Isto é confirmado nas entrevistas, sobretudo, no que diz respeito às relações entre elas e as associaçóes de trabalho, e também pelas suas afinidades com os tipos tradicionais de solidariedade, que é a base das tradiçóes populares.

Trata-se de refletir sobre os processos históricos e suas ressignificaçóes na história do tempo presente. As tradições populares formam relevantes fontes de pesquisa tanto pelos seus objetos ligados ao patrimônio material, considerando seus usos, funcionalidades, açóes sociais e econômicas, quanto à própria configuração do ambiente onde foi gerado. Assim, alinharam-se aqui as lembranças e histórias de vidas de três ceramistas do Vale do Jequitinhonha: Zezinha, Deuzani e Rita

\section{A atividade na cerâmica}



Imagem 1 - Zezinha com sua cerâmica em sua casa em Campo Buriti, Turmalina, Minas Gerais, 2016

Fonte: Acervo do autor.

A ceramista Maria José Gomes da Silva, a Zezinha, nasceu em Campo Alegre, em 1968. Zezinha, hoje, mora e trabalha em Campo Buriti, localidade vizinha à sua terra natal. Explica quando e como começou a lidar com o ofício da cerâmica: "eu comecei bem pequena. Eu morava em Campo Alegre, junto com a mamãe e os outros irmãos. Eu sou a primeira de uma família de dez irmãos, aí eu comecei junto com a mamãe a trabalhar com artesanato. Com 12 ou 13 anos e nunca parei” (Maria José Gomes da Silva, 2016).

Ela ressalta que, apesar de ter sido sua mãe que lhe ensinou a fazer cerâmica, foi o tempo que lhe deu a mestria do ofício. Zezinha diz ainda que, hoje, 
consegue viver de seu trabalho, da venda de suas peças. Ela diz também que, hoje, comercializa as peças em casa e não mais na associação - Associação dos Artesãos de Coqueiro Campo (AACC) -, criada em 1994 por um grupo de ceramistas de Coqueiro Campo.

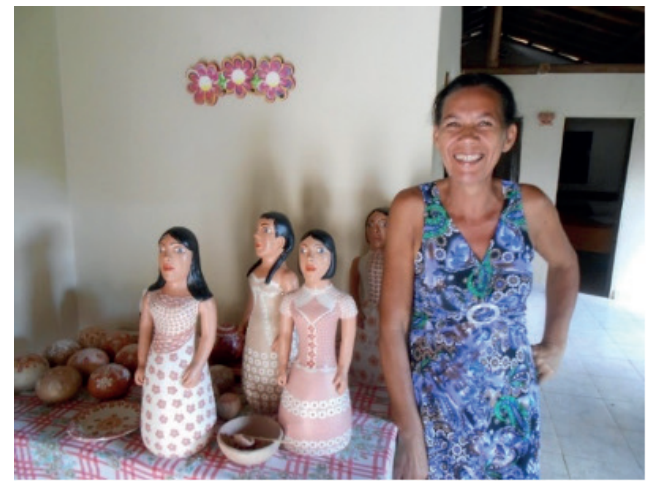

Imagem 2 - Deuzani com sua cerâmica em sua casa em Coqueiro Campo, Minas Gerais, 2016 Fonte: Acervo do autor.

A ceramista Deuzani Gomes dos Santos também nasceu em Campo Alegre, em 1965. Hoje, vive e trabalha em Coqueiro Campo. Ela também comercializa as peças em casa e não na associação. Ela é uma das artistas que recebe visitantes da cidade no Programa Turismo Solidário, do MTur. Este programa hospeda quem deseja conhecer a cerâmica da região, na casa das próprias artistas. A artesã relata como iniciou o seu processo de trabalhar com a cerâmica: "a primeira peça que eu fiz, eu tinha 6 anos. Aprendi com minha mãe mesmo e minha mãe já tinha aprendido com outras pessoas que faziam. Porque na época da minha mãe, quando ela era solteira, as moças faziam cerâmica para o enxoval delas, quando iam casar" (Deuzani Gomes dos Santos, 2016).

Ela ressalta que a cerâmica sempre ajudou nas despesas da casa e que, hoje, além de viver dessa renda, trabalha também na roça: "planto bastante coisa aqui no quintal, mas já tem muita gente que consegue sobreviver só com artesanato" (Deuzani Gomes dos Santos, 2016). 


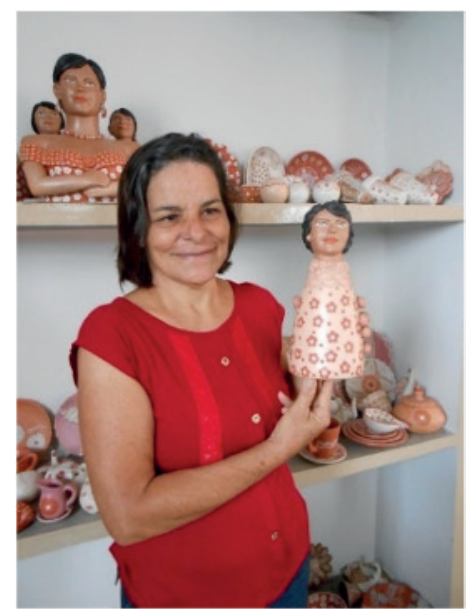

Imagem 3 - Rita com sua cerâmica na Associação dos Artesãos de Coqueiro Campo, Minas Gerais, 2016

Fonte: Acervo do autor.

A ceramista Rita Gomes Ferreira nasceu em Coqueiro Campo, em 1959. Ex-professora da escola local, hoje, mora e trabalha com o barro nessa cidade. Ela relata como iniciou o seu ofício e lembra quem foi sua mestre:

Desde pequena, eu já fazia alguma coisa de cerâmica, mas não tinha aquela vontade. Porque na época o pessoal usava mais as peças para consumo. Pote para colocar água, moringa, pratos e panelas. Foi a minha tia a minha mestre, a dona Rosa. Aí, comecei a fazer as bonecas. Eu já tinha mais de 20 anos quando recomecei. Não era também muito visto o artesanato, ainda não era comercializado. (Rita Gomes Ferreira, 2016).

Rita explica que, ainda hoje, diferentemente de Zezinha e de sua cunhada Deuzani, participa da AACC. Ela ressalta que as ceramistas se uniam antes mesmo de criar a associação. 


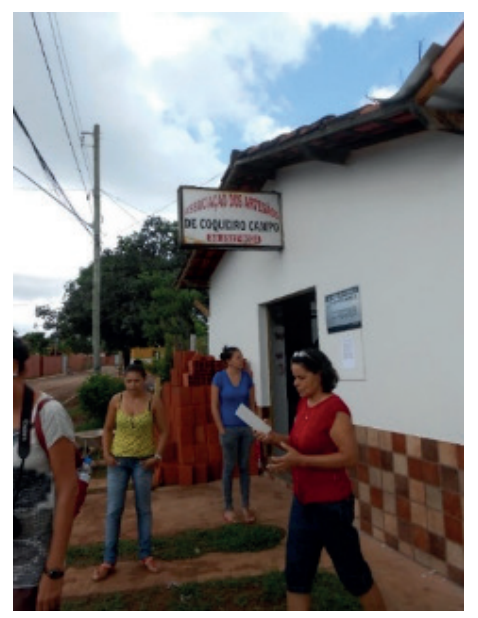

Imagem 4 - Rita em frente à Associação dos Artesãos de Coqueiro Campo, Minas Gerais, 2016 Fonte: Acervo do autor.

Ela também faz parte do Programa Turismo Solidário. Rita é uma das lideranças entre as artesãs da região. Ela diz que, hoje, consegue viver somente com a renda de suas peças: "não tenho outra renda, eu consigo viver do artesanato. Eu tenho um filho e eu criei meu filho com a renda do artesanato. Não é muito, na verdade. Mas, a gente vai sobrevivendo até hoje” (Rita Gomes Ferreira, 2016).

Em relação à administração das vendas, à receita mensal e ao controle dos gastos, Zezinha explica que não tem um controle mensal, pois ora vende, ora não, em suma, vive na incerteza. Ela diz que quem faz o balancete das vendas e cuida da parte administrativa é o seu marido Ulisses. De forma parecida, Deuzani também vive sem um controle regular dos custos mensais. Ela ressalta: "na verdade a gente não faz muito isso não. Tem que saber administrar para não ficar no vermelho. Mas, a gente náo faz ao pé da letra, entrou tanto, saiu tanto. Acho que praticamente, quase ninguém faz isso por aqui" (Deuzani Gomes dos Santos, 2016). Já Rita lembra da importância das feiras, da loja e dos clientes fixos nas vendas das peças e na administração da sua receita.

Já tem mais ou menos uns vinte anos que eu trabalho. Eu já tenho alguns clientes. A gente trabalha junto com a associação que, na verdade, por exemplo, para participar de uma feira, vai todo mundo junto, levam as peças de todo mundo na feira e aí redistribui as vendas que são feitas. E tem a loja também. A gente deixa exposto lá e, normalmente, vem bastante gente. (Rita Gomes Ferreira, 2016). 
A associação teve um papel importante na vida dessas ceramistas, mesmo que algumas delas já estejam mais independentes. Zezinha explica que o papel da associação no seu trabalho foi interessante, porque, pela associação, ela conseguiu ser conhecida pelo público.

Você participa de feiras comunitárias com o grupo todo, recebemos convites e temos a oportunidade de participar juntos. É maravilhoso. Foi muito bom a associação para mim. Hoje, eu nem estou nela mais. Então, você tem que dar oportunidade para as pessoas que ainda náo conseguiram. Porque a associação é uma coisa de ensinar você a caminhar. Quando você aprende você é independente. (Maria José Gomes da Silva, 2016).

Assim, hoje, Zezinha segue seu caminho independente da AACC e, ao mesmo tempo, ela abre oportunidade para que outras ceramistas possam participar do grupo. Deuzani também não participa mais da administração da associação, apesar de ter ajudado a fundá-la, mas acredita que é importante o papel da associação para as meninas que estão lá. A união acaba trazendo maior possibilidade para o grupo. Já Rita ainda participa da associaçáo e diz que tem muitos benefícios: "a gente procura buscar para todo mundo, porque, hoje em dia, sozinho, é meio complicado conseguir” (Rita Gomes Ferreira, 2016).

Percebe-se que, hoje, as três artesãs conseguem viver da cerâmica, e o quanto esse trabalho proporcionou uma identidade à região, apesar da falta de recursos. As artesãs explicam que no Vale o trabalho de cerâmica é realizado prioritariamente por mulheres, pois os homens desde muito tempo migram para trabalhar em outra cidade e até hoje é assim. Rita explica que a cerâmica existe há muitos anos, vem dos avós, bisavós, tataravós e que foi passando de geração em geração. E as mulheres foram sempre as responsáveis por esse trabalho. Diz ainda Deuzani:

[...] na verdade, é porque as mulheres são as que mais ficam em casa, porque os homens, aqui no Vale do Jequitinhonha - era pior, já melhorou bastante - eram visitantes só. Todo mundo migrava. Saíam todo ano no mês de abril e só voltavam em dezembro. Então, não tinha como trabalhar com cerâmica. As mulheres faziam para ajudar nas despesas da casa. (Deuzani Gomes dos Santos, 2016).

Zezinha também explica sobre esta forte relação entre a cerâmica e as mulheres:

[...] isso vem desde antigamente. É muito difícil ver um homem na cerâmica.

Tem muito pouco. É mais abrangido por mulheres. Talvez seja porque os 
maridos saíram, a mulher ficou em casa e teve uma opção a mais de estar mexendo com a cerâmica, enquanto o marido está fora trabalhando. Eu penso até que deve ter muito homem de cabeça boa para mexer com barro. (Maria José Gomes da Silva, 2016).

Assim, percebe-se que poucos homens se tornam artistas no Vale. Outro aspecto de grande relevância observado nas entrevistas é o papel central da mulher para a reprodução e manutenção da propriedade familiar. Além de cuidar da casa, Deuzani, por exemplo, desenvolve um intenso trabalho em sua propriedade, plantando e colhendo uma diversidade de produtos. Além de todo o trabalho doméstico, essas mulheres ainda produzem o artesanato para agregar um valor nos rendimentos da família.

O Vale do Jequitinhonha é tomado pela plantação de eucalipto. A indústria do carvão comprou muitos terrenos dos moradores e reflorestou a região quase por completo, não rendendo empregos aos moradores. $\mathrm{O}$ eucalipto, por drenar a água dos lençóis freáticos, prejudica a região que se tornou totalmente seca e sem condiçóes favoráveis para o cultivo. Deuzani lembra o quanto a regiáo se tornou desvalorizada, as terras dos trabalhadores rurais foram vendidas por preços baratíssimos e ressalta ainda que sucedeu um desastre ambiental na região:

[Reflorestamento] é uma peste. O maior desastre ambiental que teve foi a Acesita [empresa de reflorestamento] aqui na regiáo, deixando muitas vítimas. Não matou na hora, mas vai matando aos poucos. Com a seca. Matou todos os bichos que tinha. Todas as frutas do cerrado, acabou com tudo. Isso deve ter uns 40 anos que começou, mais ou menos. E tomou as terras do pessoal. Muitas terras foram tomadas, não foram compradas. Queimou tudo, nascentes, lagoas, todos os bichos que tinham. Foi um desastre ambiental terrível! (Deuzani Gomes dos Santos, 2016).

Ela explica que a população é muito revoltada com isso e que não tem nenhuma associação ou Organização Não Governamental (ONG) que lute contra isso: "o pequeno lutar contra o grande é muito difícil!" (Deuzani Gomes dos Santos, 2016). As entrevistadas ainda lembram a dificuldade para conseguir a lenha para usar no forno para queimar as cerâmicas, mesmo com tanto eucalipto na regiấo.

A madeira [no mato] não é boa para fazer lenha e quando você vai procurar a lenha no mato você tem que pegar a que secou lá. Você não pode cortar senão não funciona. Ela quebra sua peça ou mancha. Está funcionando assim. Quando a gente consegue pedir é que ela [Acesita] dá um pouquinho. 
Não é tanto. Eu preciso de lenha, vou lá pedir e não resolve rapidinho. Você tem que esperar e ganha muito pouquinha lenha. (Maria José Gomes da Silva, 2016).

As entrevistadas ainda lembram como é uma tarefa árdua tirar o próprio barro para a modelagem, utilizado na cerâmica. Zezinha explica como é o processo para adquirir o barro no barreiro da regiáo:

[...] os barros você encontra as cores por aí mesmo. A questão do barro é a seguinte, o barreiro lá a gente tira há muitos anos. Às vezes, faz a coleta de dois a três anos. Você tira e fica um tempo e todo mundo trabalha. Quando você vai tirar de novo está cheio de mato de novo (Maria José Gomes da Silva, 2016).

Deuzani, assim como Zezinha, fala sobre a preocupação em não degradar o barreiro. A artesã diz que desde quando ela começou na AACC - foi a primeira presidente -, uma das suas preocupaçóes era o cuidado com a ecologia, de não degradar o meio ambiente. Explica: "então, da onde a gente tirava o barro - era um pouco de barro só e muita terra vermelha -, a gente ia jogando aquela terra para trás e atrás ia nascendo a árvore do mesmo jeito. Para não degradar e não deixar chegar até o córrego" (Deuzani Gomes dos Santos, 2016). Rita também explica sobre o processo de coleta do barro e as camadas profundas da onde é tirado:

[...] o barro que a gente trabalha não é como esse que a gente vê aqui em cima da terra. Para descobrir ele, a gente tem que tirar uma parte da terra, para chegar no barro e depois a gente volta essa parte que náo precisa e coloca lá. É bem profundo. Você meio que revira o barro. E, mesmo no local do barro, o que a gente retira da terra, a gente procura repor o local para não danificar. Na verdade, como hoje há bastante artesãs, a gente escolhe uma época do ano, com uma máquina, limpa o lugar e normalmente a gente paga alguém para retirar ele. Porque, a gente tem que fazer uma seleção do barro para trabalhar. (Rita Gomes Ferreira, 2016).

O processo de como obtém os vários tipos de barro e as diversas cores para suas esculturas, é lembrado por Zezinha:

[...] é nesse barreiro que você tira o barro da modelagem e, depois, essas outras cores você acha em outros locais. Lá no lugar do barro de modelar, só dá branco, cor-de-rosa, só. Um amarelo claro. E, as outras cores você vai 
procurando. Alguém encontra. Você compra na mão da pessoa que tem o barro (Maria José Gomes da Silva, 2016).

Observa-se que os vários tipos de barro dão a cor da cerâmica do Jequitinhonha. Do barreiro da região, são tiradas as três cores básicas vindas da terra: branco, cor-de-rosa e amarelo. Deuzani diz: "você tem que fazer o teste muitas vezes, porque às vezes a cor é bonita, mas não fixa na peça. É todo um processo de experimentação. Cada cor, a gente tem que experimentar" (Deuzani Gomes dos Santos, 2016). Quando vai ao forno, as artesãs explicam que a cor do barro se transforma. Ressalta Zezinha que o branco:

[...] se transforma. Geralmente, o barro cru é marrom, quando ele está molhado é bem escuro e depois que queima fica mais para um branco. Clareia. Quando você está na modelagem você não está preocupada com cores. As cores vêm depois que a peça está seca e que você tem que pintar ela para ir ao forno. Aí sim você tem que se preocupar com as cores. Mas, a modelagem é uma só. (Maria José Gomes da Silva, 2016).

A artesã explica que somente os detalhes, como os olhos e as bocas, são pintados com tinta industrializada, pois o resto das cores é todo feito com o barro da região. O barro é peneirado até tornar-se finíssimo para ser usado como pigmento para olear. Antes de ir ao forno, as cores têm outros tons que se transformam, como afirma a entrevistada em relação ao branco. Deuzani também lembra de como acontece a transformação das cores: "há uma diferença nas cores e o branco muda de cor no forno. Com a temperatura, muitos mudam de cor. Na hora que a gente estiver fazendo a pintura, você tem que imaginar a peça pronta. Você tem que guardar na cabeça como ela ficaria depois de pronta. De memória" (Deuzani Gomes dos Santos, 2016). Este processo é muito refinado, pois as artesãs devem imaginar, associar, como será que ficará o barro oleando-o: o vermelho vem do barro amarelo; a tabatinga é cinza. Assim, a artesá tem que olear a partir de uma escala cromática que se transformará. Rita também explica sobre os diferentes tipos de cores e sobre o processo de transformação das cores do barro:

[...] o básico, que normalmente a gente usa, é o vermelho, o branco, o amarelo e daí surgem as outras cores. O branco, quando cru, antes de queimar, ele é preto. Quando queima, fica branco. No forno, vai mudar porque a gente modela a peça e, depois dela modelada, a gente passa outra camada que a gente chama de oleio. É o que vai dar o acabamento lisinho e daí a pintura e depois a queima. A gente vai testando. Mas, são várias outras 
cores que ainda precisam misturar, precisam testar. Porque ele tem que ter uma textura que, quando queimada, não solte da peça, ou lavando também não solte. É uma técnica. Só para modelar uma boneca de $50 \mathrm{~cm}$ eu gasto uns dois dias. Aí tem a secagem, a gente deixa no sol, tem a preparação do oleio, depois a pintura e depois a queima. Para pintar, geralmente, um dia para uma boneca de $50 \mathrm{~cm}$, ou mais um pouquinho. Depende do desenho que você for fazer. Se tiver muitos detalhes, aí demora um pouquinho mais. (Rita Gomes Ferreira, 2016).

Zezinha explica como é todo o processo, desde quando o barro sai do barreiro até a finalização de suas peças: "primeiro se busca o barro e leva para a gangorra, soca, peneira e depois amassa. Quando terminou de modelar, vem o acabamento, aí, se pinta e vai para o forno por $7 \mathrm{~h}$ de queima. No caso das bonecas, depois ainda tem o retoque" (Maria José Gomes da Silva, 2016). Lembra ainda que muitos cuidados devem ser tomados para não se perder o material:

[...] o cuidado começa desde a preparação do barro, da modelagem, da secagem das peças. Você tem que ter um certo cuidado, por exemplo, não colocar a peça molhada no sol de repente, ela pode rachar. Tem que esperar ela secar um pouco na sombra, depois pôr ela no sol. Na modelagem, se você enxergar vestígio de bolha você tem que tirar. Quando você arruma no fogo, você náo pode pôr o fogo de uma vez. É uma série de cuidados. Você não tem manual. Não tem controle de temperatura. É você mesmo que vai controlando o tempo. (Maria José Gomes da Silva, 2016).

Deuzani ainda recorda dos cuidados a serem tomados para náo perder material: "não pode deixar o barro ao ar livre, seca. A gente coloca em garrafa PET, descartável, ou vasilha de plástico, desde que esteja bem tampado. Divido por cores. O barro, se tiver preparado para trabalhar, tem que colocar em um plástico para proteger, senáo seca" (Deuzani Gomes dos Santos, 2016). 


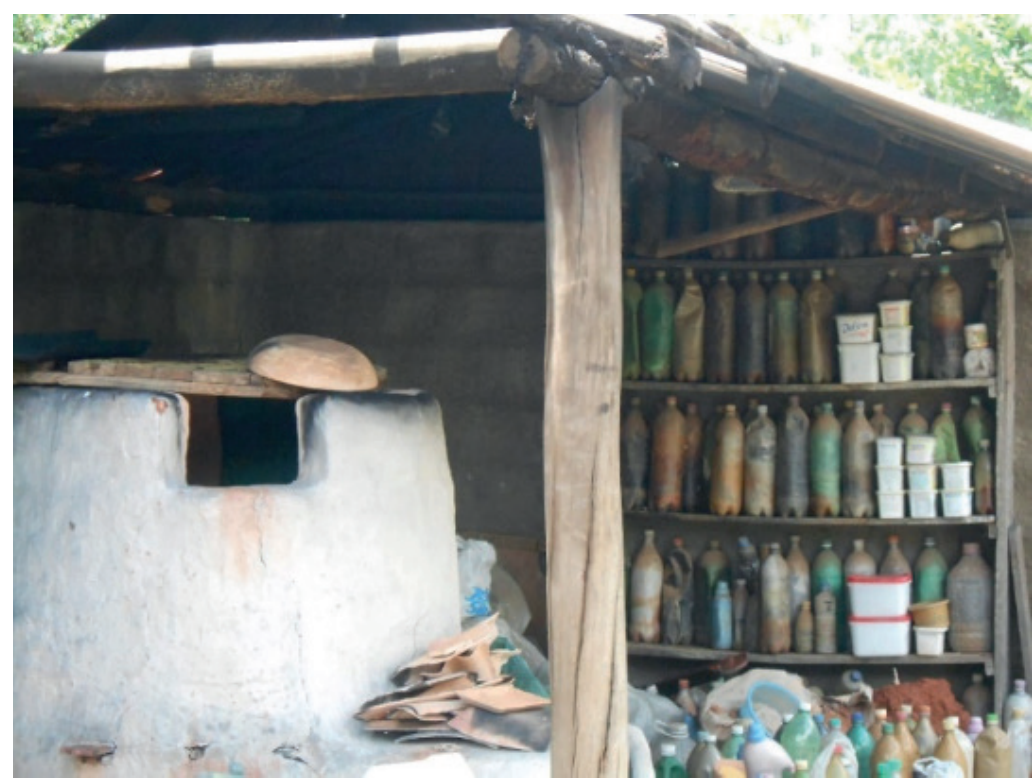

Imagem 5 - Forno com as garrafas de diferentes tipos de barro na casa de Rita, em Coqueiro Campo, Minas Gerais, 2016 Fonte: Acervo do autor.

Assim, observa-se a partir dos depoimentos que os vários tipos de barro dão cor ao artesanato do Vale. A não ser por pequenos detalhes, como olhos e cabelos, as artistas não usam tintas industrializadas em suas peças. O barro é peneirado até se transformar em um pó que será usado como um tipo de tinta para olear. Há quatro cores básicas provenientes da terra: vermelho, branco, amarelo e cor-de-rosa. Entretanto, as artesãs ressaltam que antes de irem ao forno, as cores apresentam outros tons. Deste modo, percebe-se o grau de sofisticação dessas artesás, que devem imaginar como ficará a peça a partir de uma escala cromática, que tem como base a associação de cores, observando assim que essas artesâs possuem um raciocínio cromático muito elaborado. Com isso, diferente do artesanato de outras regióes do Brasil, as peças no Vale do Jequitinhonha não são pintadas, e sim oleadas. Do barro, as bonecas começam a nascer das mãos das artesãs. Tudo começa com um rolinho de barro, em forma de círculo bem fino, formando a base da obra. Em seguida, o barro, sobreposto em discos, se transforma em saia, e, por fim, criam o tronco e o rosto. Formam-se as bonecas e as noivas características das obras e das vidas dessas ceramistas, ressaltando a ligação entre trabalho, arte e vida no processo de criação do Vale do Jequitinhonha. 


\section{Biografias e obras: \\ Zezinha}

Maria José Gomes da Silva é a autora das bonecas mais procuradas de Coqueiro Campo. Zezinha explica sua origem:

[...] nasci lá [na zona rural de Campo Alegre]. Meu pai veio de uma família de artesãos. A mãe dele até trabalhava como artesã. A gente é uma família de dez irmãos. Hoje, está todo mundo espalhado. E minha vida sempre foi trabalhar com artesanato. Eu ajudava papai e era servente, às vezes eu trabalhava na roça, às vezes, ia para o artesanato, e ainda cuidava dos meninos, uma penca de meninos pequenos. Aí, eu cresci lá, até os 21 anos desse jeito. Mas, era uma vida muito sofrida. Você trabalhava muito e náo podia comprar nada. Nem uma sandália, nem um chinelo. $\mathrm{O}$ que a gente podia comprar vinha do artesanato. A gente levantava lá na manhã da segundafeira, vinha no barreiro que é aqui perto da minha casa, quem aguentava barro na cabeça, levava, socava o barro e modelava as peças para fazer a feira no sábado seguinte. Você fazia tudo dentro de uma semana. Modelava, pintava e queimava. Na sexta-feira, arrumava no forno e terminava a queima por volta das dez horas da noite. E uma hora da madrugada, você levantava para tirar as peças de novo do forno para levar lá para o asfalto, para pegar o ônibus para ir à feira. Era essa a rotina. (Maria José Gomes da Silva, 2016).

Zezinha é filha de artesãos, o ofício foi passado de pai para filha. Observa-se que Zezinha trabalhou muito pesado na vida. Precisava, no início, ir ao barreiro para colher o barro, tarefa dura, pois com enxada e balde na máo realizava a tarefa pesadíssima de virar a terra à procura do veio certo do tom que precisava. Depois, carregava os baldes pesados no caminho de volta para casa. O trajeto era feito a pé ou a cavalo, com o barro carregado na cabeça. A artesã já conviveu com os dois lados, antigamente, fazia a tarefa dura de pegar o barro, mas, hoje, não precisa ir buscar o barro. Zezinha casou com Ulisses e teve duas filhas. Ela lembra:

[...] tudo isso era muito trabalhoso! Eu pensei quando eu casar não vou mexer com isso, é vida muito sofrida! Quando eu casei, parece que deu uma melhorada. Deu para descansar, para dormir, não carreguei tanta coisa na cabeça. Mas, parece que você traz, está impregnado em você o jeito de mexer com barro. Parece que não tem outra profissão e eu comecei de novo. Mas, em um outro estilo, mais tranquilo, depois eu tive minhas meninas, Ulisses era migrante. (Maria José Gomes da Silva, 2016). 
Ulisses, como quase todos os maridos da região do Vale, passava oito meses do ano fora trabalhando na lavoura, no corte da cana, ou como servente, ou o serviço que achasse para fazer dinheiro, em São Paulo. Foi migrante até a filha do casal, Cláudia, completar dois anos. Então, Ulisses foi tomar conta das meninas, cuidar de casa, arrumar a casa, lavar roupa, buscar lenha e Zezinha foi trabalhar só no artesanato. Desta forma, o casal conseguiu se organizar e a situação melhorou muito. Ulisses, hoje, é praticamente um assistente ou administrador, e, muitas vezes, é marchand e empresário de Zezinha. Com sua ajuda, Zezinha se dedicou ao artesanato e constituiu uma família. O casal tem duas filhas, Claudia e Aline, e uma neta, Lorena.

Hoje, Zezinha já consegue vender suas peças por um bom preço e sustenta a família com o seu trabalho. Com verba para comprar o barro, não precisa mais ir ao barreiro e tem mais tempo para se dedicar à sua arte e, continuando a tradição familiar, envolveu todos da família nesse ofício.

Despertou o interesse delas [das suas filhas]. Elas falaram: 'vamos trabalhar juntas'. E eu dei oportunidade a elas [de ficar em casa] e todas duas pintam as peças para mim. Aí, depois que queima as peças, eu volto de novo a pegar nas peças, porque eu vou pintar cabelo, fazer olho, batom. Mas, cada um tem uma parte no trabalho. (Maria José Gomes da Silva, 2016).

Juntamente com a família, Zezinha tem hora para trabalhar, o que ela chama de expediente. Ela trabalha numa casinha que fica no centro do seu quintal. Acorda às $5 \mathrm{~h}$; faz a primeira refeição, o café da manhã, às $8 \mathrm{~h}$; faz um lanche no intervalo; retorna ao trabalho às $11 \mathrm{~h}$; almoça às $14 \mathrm{~h}$; lancha às $16 \mathrm{~h}$ e termina o dia de trabalho.

A casa de Zezinha faz parte de sua obra. É um museu a céu aberto. Logo na entrada, deparamos com uma estrada com uma cerca decorada com cabeças de esculturas de animais como cachorros, famílias de gansos e macacos. No jardim, além dos animais, encontramos flores, plantas, bonecas e as noivas, tudo feito de barro. Percebe-se o estilo barroco deste espaço, repleto de excessos, narrativas e detalhes. Como se uma peça levasse a outra, em um movimento sem fim. Para Daniela Name (2008), Zezinha é "a Frida Kahlo do Jequitinhonha”, pois Kahlo também fazia da própria casa um espelho de sua obra e sua vida. $\mathrm{Na}$ varanda, destacam-se as cortinas de contas pintadas com tabatinga, móbiles, objetos de parede e, no meio desse paisagismo, sobressai um caramanchão com uma cabeça de mulher na parte de cima. 


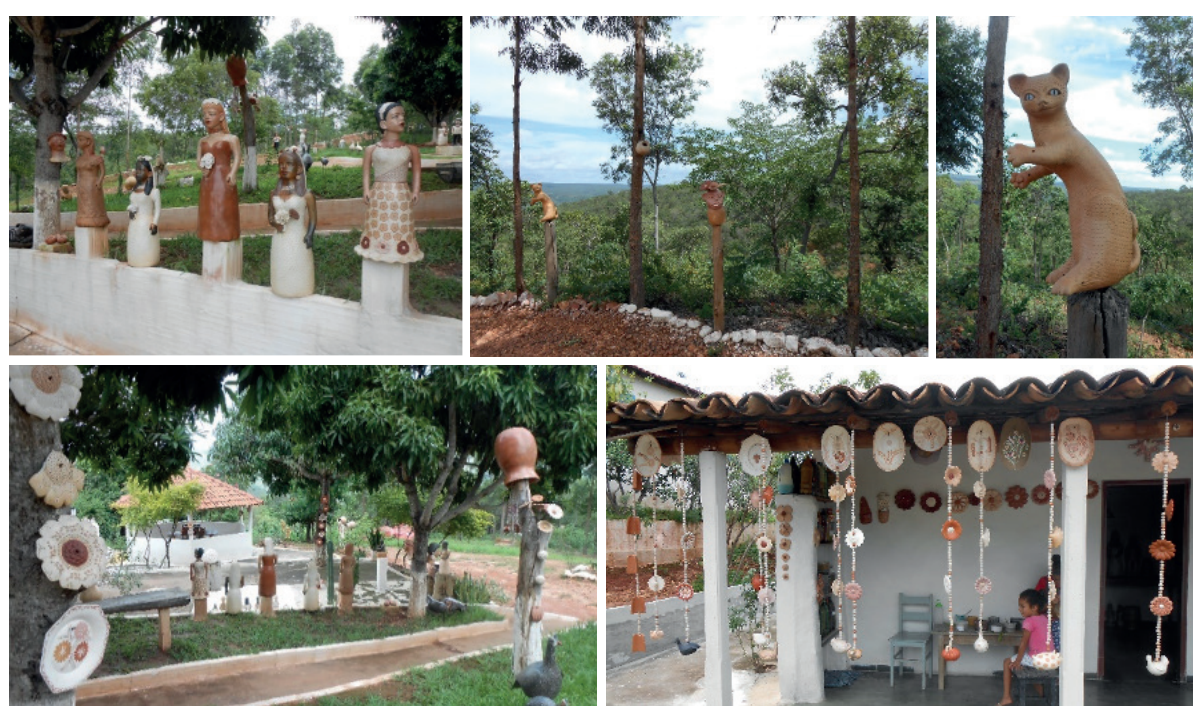

Imagens de 6 a 10, em sentido horário - Muro com bonecas e noivas; cerca com animais e rostos; um dos animais da cerca em destaque; varanda com móbiles; jarros e flores no quintal; tudo de barro, realizado por Zezinha, em sua casa, em Campo Buriti, Minas Gerais, 2016 Fonte: Acervo do autor.

Entrar na casa de Zezinha e deparar com os rostos com pescoços de animais e pessoas colocados nas cercas é uma sensação extraordinária. Como se sua casa fosse um museu, percebe-se o quanto Zezinha tem prazer em enfeitar sua casa, construí-la pensando em cada detalhe. É uma arquitetura lúdica e criativa. Diz Zezinha: "simplesmente decoro. Fica bonito, você não enjoa. Quando eu penso que podia fazer uma peça assim para mim, eu já fico eufórica. Quero realizar logo. Mas, o trabalho em si é lento. Eu faço e cai na graça do povo! Todo mundo gosta!" (Maria José Gomes da Silva, 2016). Ao responder sobre a possibilidade de transformar e oficializar sua casa em um centro cultural de suas obras, Zezinha fala: "aqui no meu lugar? Eu penso que, quando eu morrer, isso aqui morre junto comigo. Requer um carinho táo grande cuidar disso e eu não vejo esse carinho" (Maria José Gomes da Silva, 2016). Zezinha explica que a casa dela é aberta a todos que chegam para conhecer sua obra: "minha casa fica em exposição, para todo mundo que chega, eu falo que meu quintal é minha sala de visita" (Maria José Gomes da Silva, 2016).

Apesar de trabalhar com o barro, Zezinha se preocupa com a limpeza da sua casa. Isto se pode perceber pela sua aparência, arrumada e feminina como suas 
bonecas. Percebe-se que os trabalhos feitos por Zezinha são muito autobiográficos, ou seja, retratam muito a vida de quem os faz, inclusive as bonecas tendo feiçóes semelhantes de quem as molda. Zezinha explica:

[...] eu concordo. Se a gente for olhar a boneca, parece a dona. Incrível! Você acaba levando a sua vida para o barro. É uma coisa inexplicável. Sem querer! Sem pensar, você acaba fazendo uma mulher com criança mamando no colo, mulher sozinha. Acho que eu sou muito família, né? Gosto de fazer tudo em grupo de família. Família de macaco, família de tatu. (Maria José Gomes da Silva, 2016).
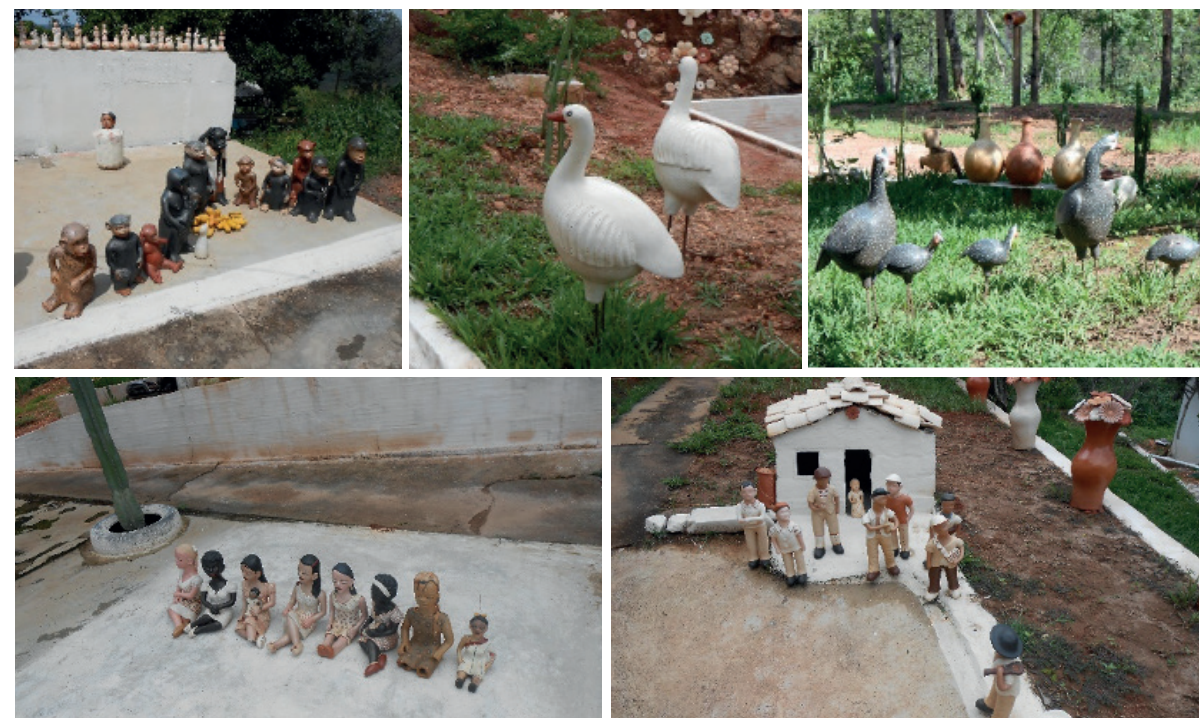

Imagens de 11 a 15 - Famílias de animais e pessoas feitas de barro por Zezinha no jardim de sua casa, em Campo Buriti, Minas Gerais, 2016 Fonte: Acervo do autor.
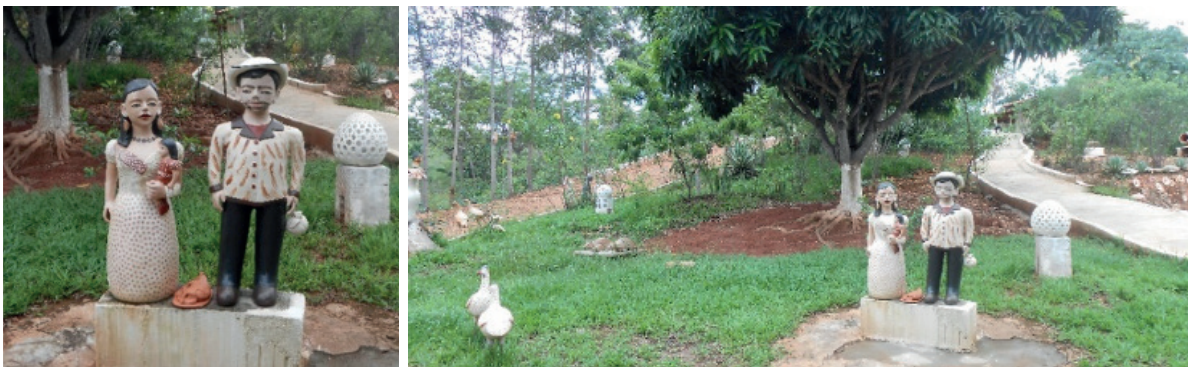

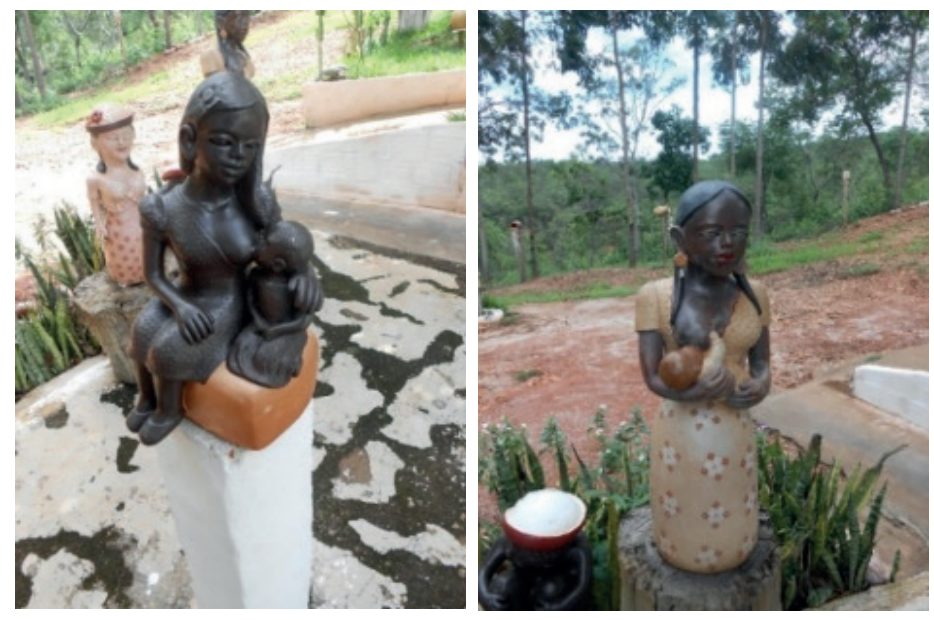

Imagens de 16 a 19 - Pai, mãe e filha; mãe e filha; feitas de barro por Zezinha no jardim de sua casa, em Campo Buriti, Minas Gerais, 2016 Fonte: Acervo do autor.

Observa-se a referência ao tema família em todas essas peças. E o quanto suas bonecas têm um excesso de detalhes, como se fossem um bordado, uma renda no barro. O estilo das bonecas e das noivas de Zezinha é extremamente feminino, lembrando muito do rococó, com cores claras, excesso de ornamentos e elegância.
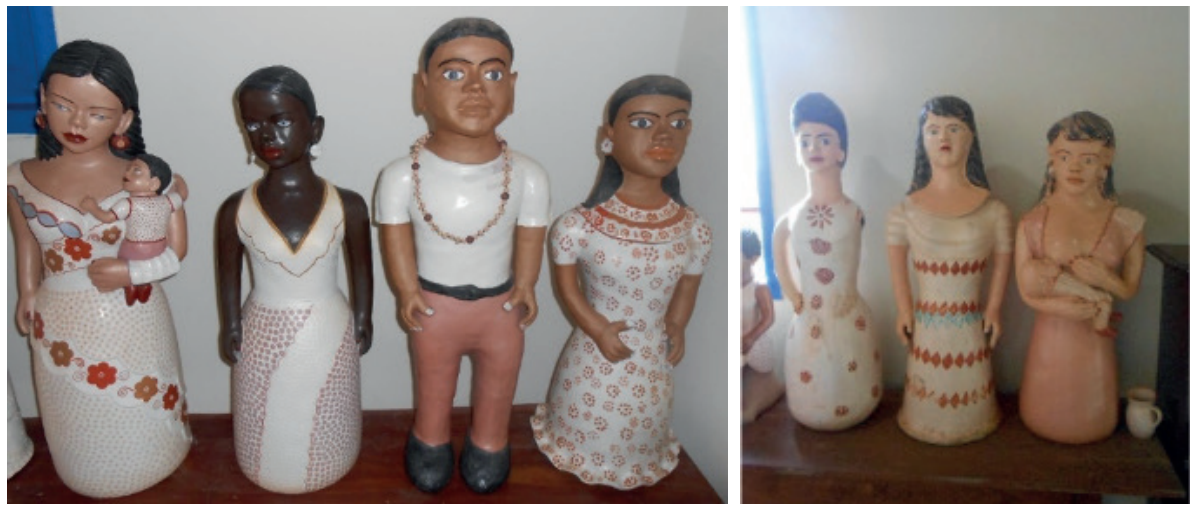

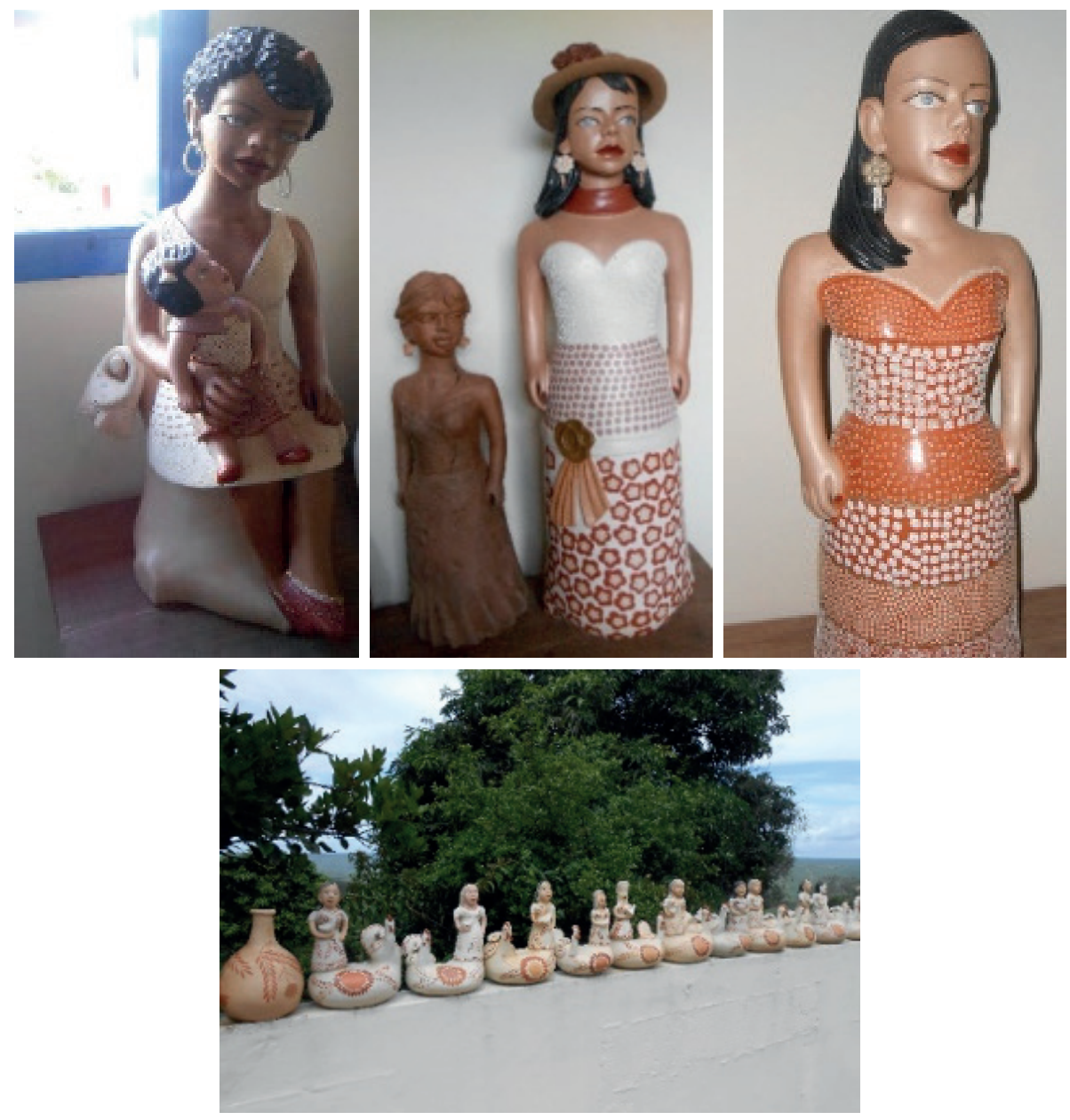

Imagens de 20 a 25 - Variadas bonecas, um boneco e peças antropozoomórficas (galinha com mulher) feitas de barro por Zezinha no interior de sua casa, em Campo Buriti, Minas Gerais, 2016 Fonte: Acervo do autor.

Percebe-se que, no meio de tanta boneca, Zezinha criou um homem. Tema raro no Vale. Além das bonecas, Zezinha faz também peças antropozoomórficas, que misturam mulheres e galinhas, por exemplo. Mas, o tema em grande destaque na sua obra, assim como na de todas artesãs do Vale, é a noiva. 

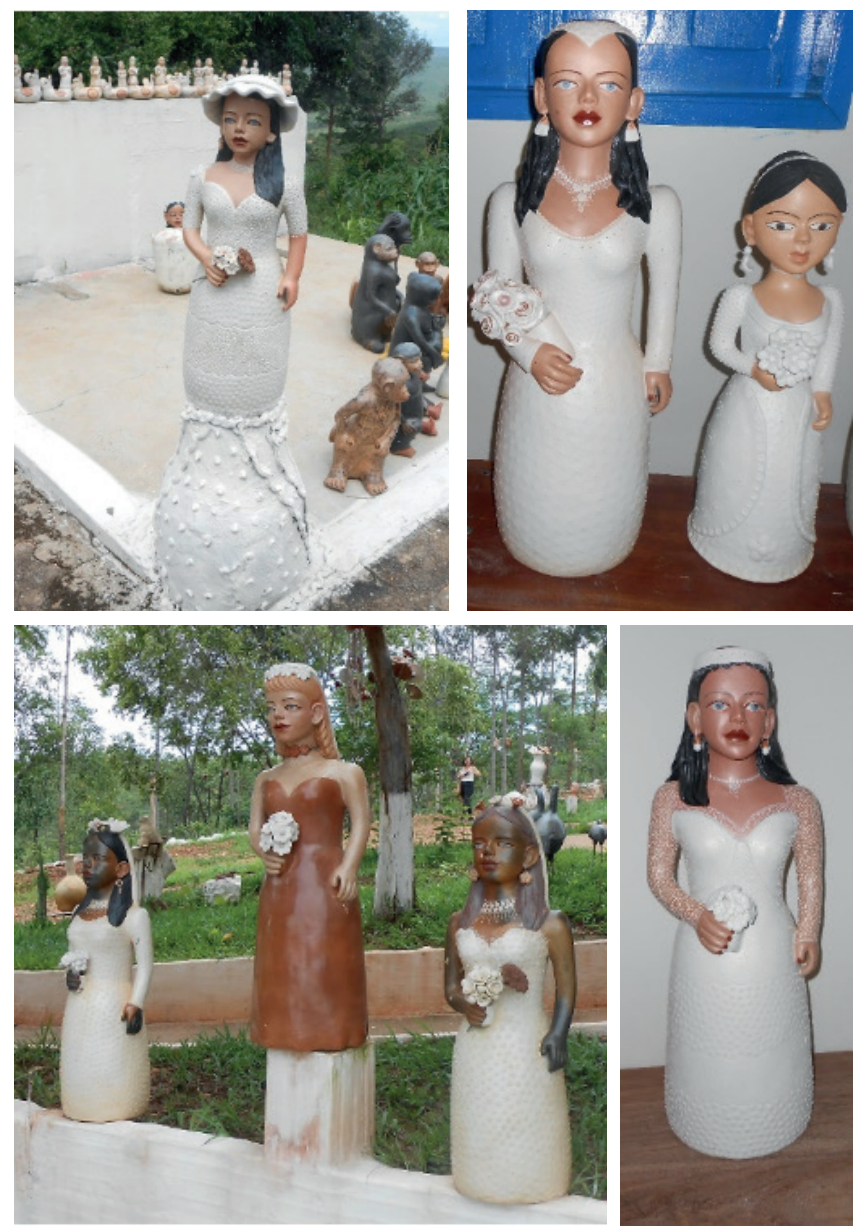

Imagens de 26 a 29 - Noivas feitas de barro por Zezinha no quintal de sua casa, em Campo Buriti, Minas Gerais, 2016

Fonte: Acervo do autor.

As noivas de Zezinha são as peças mais procuradas e conhecidas do seu trabalho. São geralmente feitas sós, sem o noivo. Isto ocorre devido ao fato de os homens migrarem e as mulheres ficarem sozinhas para criarem seus filhos: "acho que é essa questão mesmo. Os homens iam embora para São Paulo. Ficavam só as mulheres e os filhos em casa cuidando de roça, criação e artesanato. As noivas, por exemplo, ficam sozinhas no barro" (Maria José Gomes da Silva, 2016).

Devido a essa "promessa de marido" após o casamento, as artesãs recebem o nome de "viúvas de marido vivo". As noivas expressam a dificuldade e a solidão 
das mulheres do Vale para cuidar da lavoura, da família, da casa e dos filhos sem os maridos. Diz Zezinha:

[...] você sempre planta ao redor de casa. Você sempre tem uma rocinha. É difícil você cuidar de menino, da casa e das criaçôes. Tudo está ali sob sua responsabilidade. Mas, hoje, ele [marido] está sempre em casa. Já dei conta de criar os meninos, graças a Deus. Hoje, todo mundo está envolvido no trabalho. É um trabalho em conjunto. (Maria José Gomes da Silva, 2016).

O trabalho de Zezinha é muito respeitado pelas ceramistas no Vale. Para fazer uma noiva de mais ou menos $50 \mathrm{~cm}$, ela leva de cinco a doze dias. As noivas prontas com seus buquês e acessórios apresentam um trabalho refinado e com quantidades de detalhes. Zezinha é conhecida pelo seu virtuosismo, pois trata os vestidos das noivas com detalhes, com um enorme repertório de bordados e flores feitos para as roupas, além dos brincos e rendas, tudo de cerâmica. Nas suas peças, o que chama a atenção é a delicadeza da fisionomia dos rostos. É como se as noivas tivessem um pouco dela, pois algumas bonecas tem suas feições, principalmente as sobrancelhas. Em relação à personalidade das noivas, Zezinha explica: "tem umas que saem solitárias, outras cheias de esperança. Umas mais alegres. Eu acho que varia do dia e do astral que você está. Se você está feliz, faz noivas mais felizes. Às vezes, está um pouco cansada, faz noivas mais cansadas" (Maria José Gomes da Silva, 2016). Assim, compreensão e amor são uma marca do Vale, as bonecas grávidas e as noivas são sempre muito procuradas pelo público. Diz Zezinha: "viraram uma marca registrada. Volta e meia alguém quer uma noiva" (Maria José Gomes da Silva, 2016). Deste modo, Zezinha diz que o forte mesmo é a boneca, a noiva, pois todos querem as noivas "viúvas de marido vivo". O que é surpreendente no Vale é que essas mulheres ora fazem tarefas duras, pesadas, para homens e ora, no momento seguinte, criam vestidos de noiva com rendas delicadas e femininas. Isso ocorre também nas obras das outras ceramistas, como as noivas de Deuzani e Rita.

\section{Deuzani}

Deuzani Gomes dos Santos é artesã e poetiza e tem uma das obras mais reconhecidas da regiáo. Aos 11 anos, sua mãe separou-se do seu pai. Deuzani, na separação, ficou com ele, que não a deixava sair de casa e a usava como arma para atrair a mãe de volta para casa. Quando completou 15 anos, fugiu no meio do mato para encontrar e viver com a máe que morava em Campo Alegre. Dois 
anos depois, casou-se com Joaquim, que foi seu marido até ele morrer em 2014. Ela lembra: "nasci na comunidade de Campo Alegre que é mais velha do que essa na cerâmica. Depois, eu casei e mudei para cá [Coqueiro Campo] e veio muita moça de Campo Alegre que também casou e veio aqui e aí nós nos reunimos para formar uma associação" (Deuzani Gomes dos Santos, 2016).

Deuzani é membro da extensa família Gomes, saída de Campo Alegre, Turmalina, para casar-se com um homem de Coqueiro Campo. Segundo Frota (2005), seu caso não é o único, havendo mesmo a suposição de a comunidade de ceramistas de Campo Alegre ter-se formado através de casamentos como esses. Permanecem elas a desempenhar a arte tricentenária da sua terra de origem, à qual adicionam novas formas, decorrentes, é claro, da mudança de vida e lugar que experimentam. Deuzani foi uma das mulheres que criou a associação de Coqueiro Campo. Ela faz parte do Programa Turismo Solidário e recebe hóspedes, que vêm de fora, na sua casa. O estilo da casa de Deuzani é mais clean do que o estilo barroco da casa de Zezinha. A casa de Deuzani, sendo dividida na parte maior, da frente, com sala, quartos e banheiros, e na parte dos fundos, cozinha, que fica do lado de fora da casa, num quintal coberto que aproveita o fogáo à lenha. Ao fundo, ainda tem uma outra casa menor onde ela trabalha.

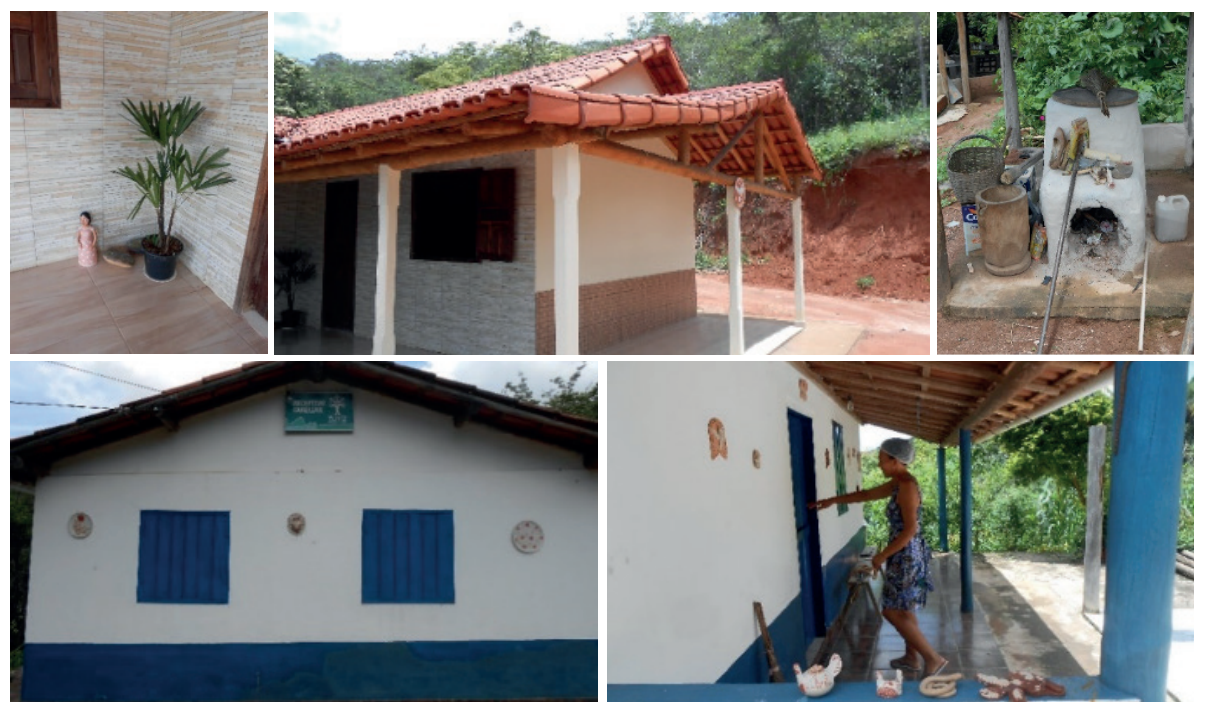

Imagens de 30 a 34, em sentido horário - Frente da casa; Lateral da casa; forno no quintal; Atelier nos fundos da casa; Varanda do Atelier de Deuzani nos fundos de sua casa, em Coqueiro Campo, Minas Gerais, 2016 Fonte: Acervo do autor. 
Deuzani construiu esta casa em Coqueiro Campo com o apoio do marido Joaquim. Mas, mesmo casada, continuou muito tempo só, como a maioria das mulheres do Vale. Joaquim também era migrante:

[...] casei e tive três filhos. O meu marido ajudava a sustentar também. Ele faleceu tem quase dois anos. Mas, bastante parte do dinheiro da casa era daqui da cerâmica. Ele ia trabalhar fora também. Cuidei dos meninos quase sozinha. A gente tem que dar conta de casa, das crianças, do serviço, da roça. De tudo. Ele ficava em São Paulo. Trabalhava em tudo o que é lugar em São Paulo. Trabalhou em Catanduva, Barueri... Como operário, em obra, em construção civil. Só na cadeia do Carandiru, ele trabalhou muito tempo. (Deuzani Gomes dos Santos , 2016).

Deuzani explica porque as mulheres ceramistas do Vale do Jequitinhonha, quando casam, não acompanham o marido para São Paulo ou para o lugar que eles vão trabalhar:

[...] a vida lá é mais difícil. Você vai com 2 ou 3 meninos para São Paulo para morar de aluguel? Vai ter que pôr os meninos em algum lugar ou pagar alguém para cuidar deles. Então, se você conseguir trabalhar seu dinheiro vai ser só para os meninos e para o aluguel, isto se der. E o marido continua a mesma coisa. Quando você volta para casa não está estruturado nem lá e nem aqui. E, aqui, a mulher vai estruturando, construindo e arrumando a casa, vai fazendo alguma coisa. Ele de lá vai mandando dinheiro e ela aqui vai estruturando. Quando ele vier embora, ou não puder mais trabalhar, eles têm uma casa e os filhos encaminhados. (Deuzani Gomes dos Santos , 2016).

A ceramista explica sobre o trabalho em família, tão comum no Vale: "tive três filhos. Duas meninas, que trabalham na cerâmica aqui comigo, e meu filho, que inclusive fez o presépio. Mas, ele não gosta de fazer. Faz as peças muito bonitas, mas ele acha que não dá para um pai de família dar conta de manter a família só com a cerâmica” (Deuzani Gomes dos Santos, 2016). 

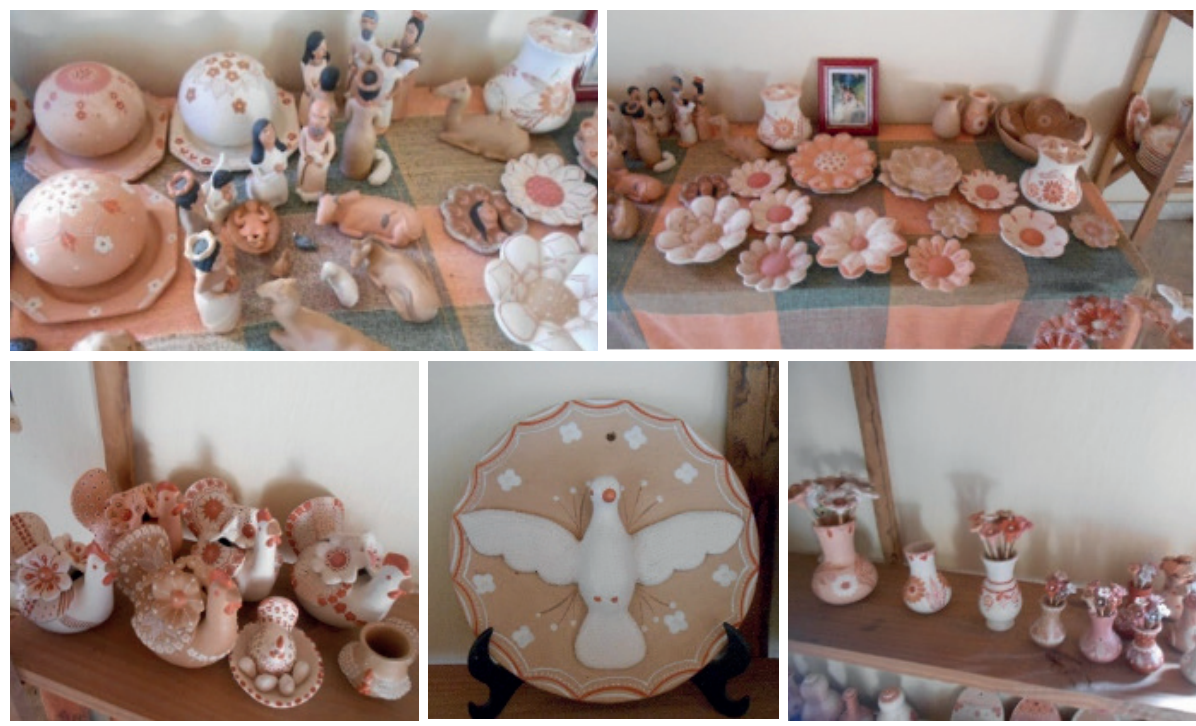

Imagens de 36 a 40, em sentido horário - Presépio (feito pelo filho de Deuzani), pesos para papel; vasos com flores; Divino; e galinhas, tudo feito de barro por Deuzani e família, em Coqueiro Campo, Minas Gerais, 2016 Fonte: Acervo do autor.

Os objetos funcionais como os pesos para papel, os cinzeiros e os vasos de flores, são característicos na cerâmica do Vale. As flores e os desenhos no barro de Deuzani mostram o virtuosismo da artista no acabamento de cada pétala de flor, de cada objeto. Assim como o seu Divino. Isto também ocorre nas suas peças zoomórficas, como as suas galinhas. Mas, onde Deuzani mais expressa o seu talento é nas bonecas. Ela lembra que sempre gostou de fazer bonecas desde sua infância quando era incentivada pela mãe.

Quando eu era pequena, minha mãe não tinha dinheiro para compra e nem tempo para fazer boneca. Ela trabalhava 15 a 16 horas por dia. Náo tinha como ela parar para fazer boneca de barro. Aí, quando a gente pedia muito, ela dizia faz de sabugo! Faz boneca de sabugo! Aí, ela dava para a gente um pedacinho de pano, uma fita, a gente amarrava no sabugo, ficavam os bracinhos, aí, amarrava embaixo, ficava a sainha. E ela pintava com carvão, o olho e a boca. Beleza! A gente brincava o dia inteiro. A boneca tinha um nome até meio dia e de meio dia para cá, outro, para aproveitar! E no outro dia já era outro! (Deuzani Gomes dos Santos, 2016). 
A arte de fazer bonecas de sabugo se transformou na de barro. Suas bonecas são das mais conhecidas do Vale.
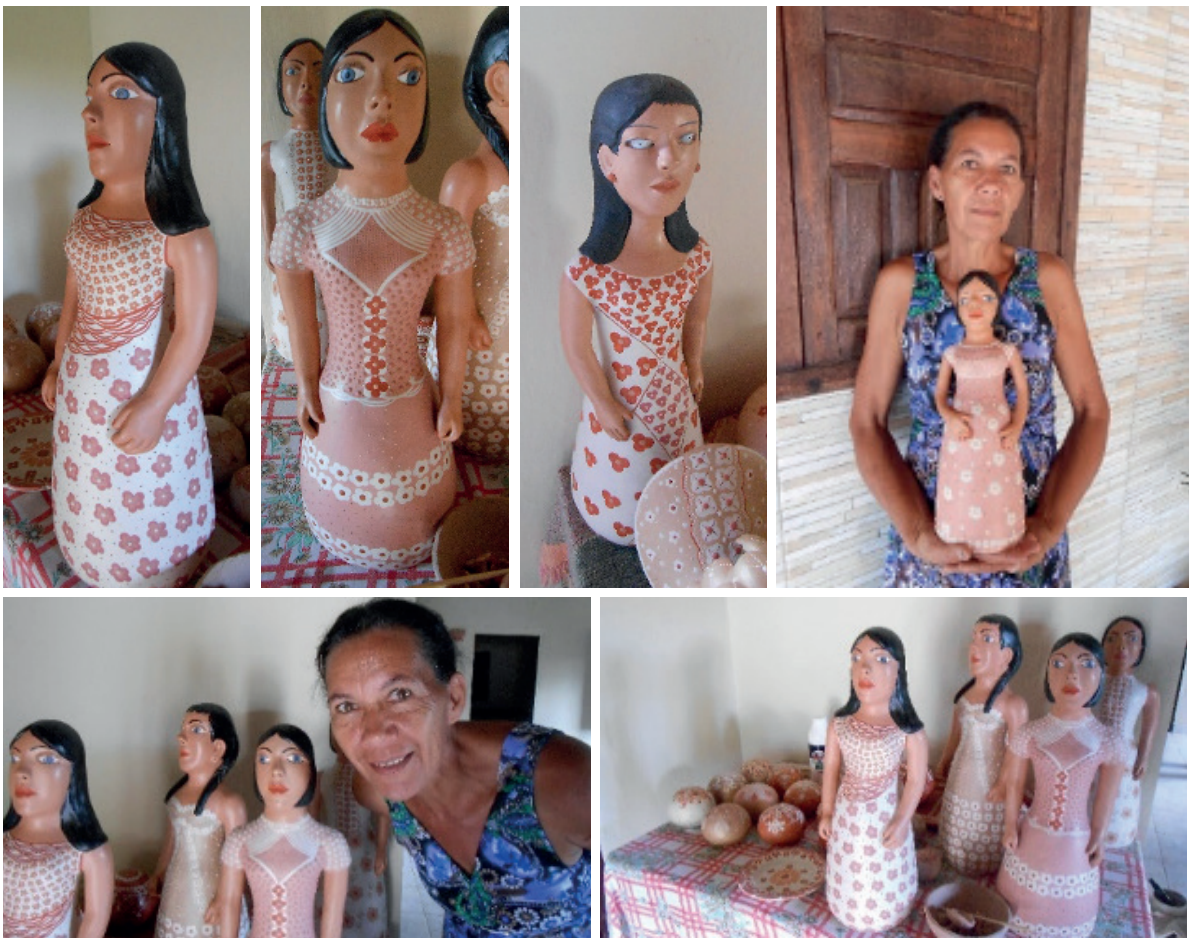

Imagens de 40 a 45 - Bonecas feitas de barro por Deuzani, criadora e criaturas com grande semelhança, no atelier de sua casa, em Coqueiro

Campo, Minas Gerais, 2016

Fonte: Acervo do autor.

Algumas vezes, as bonecas têm saias, outras, elas passam a ser moringas, transformadas em objetos funcionais. Suas bonecas têm sempre os olhos azuis e as feiçóes de seu rosto. Isto acontece com todas as entrevistadas. É um trabalho autobiográfico mesmo que inconsciente.

Ah! Tem muito a ver comigo. Não tem como você trabalhar com uma peça manual sem expressar aquilo que você está sentindo na peça. Você pega um torrão de barro, tira um pedaço de barro da natureza e transforma ele em uma decoração para colocar em qualquer casa, casa de luxo, é muito gratificante para a gente. Saber que passou pelas suas máos. (Deuzani Gomes dos Santos, 2016). 
As bonecas de Deuzani expressam não só sua fisionomia, como a solidão; sem parceiros, revelando a vida de solidão da sua criadora na terra seca do Vale. Isto se verifica também em suas noivas sem companheiro para lhe dar o braço.

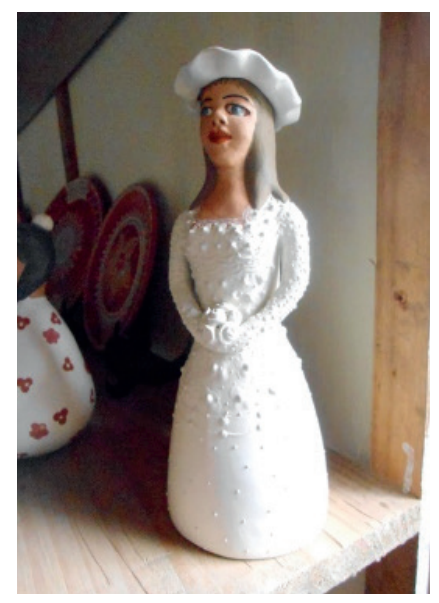

Imagem 47 - Noiva feita de barro por Deuzani no atelier de sua casa, em Coqueiro Campo, Minas Gerais, 2016

Fonte: Acervo do autor.

Assim, observa-se a noiva de Deuzani também sozinha, com o buquê na mão e acessórios como o chapéu. A solidão das noivas do Jequitinhonha é propagada nas poesias escritas pela artesã, assim como também no barro. Deuzani expressa através das mãos a sua alma. As moças da região são conhecidas como "viúvas de marido vivo", por enfrentarem a vida na solidão, longe dos seus companheiros. Ressalta a artista: "aqui, não pode ter mulher se não for guerreira não! Tem que ser igual ao cacto mesmo. Tem que ser bem resistente, tem que se proteger. Ter o espinho para se proteger, porque a gente passa a maior parte do tempo só" (Deuzani Gomes dos Santos, 2016). Deuzani, tão articulada e inteligente, representa bem as artesãs do Jequitinhonha que criam noivas tão fortes. Criadoras também enfrentam uma vida solitária, encarando a realidade com dureza e poesia.

É a força e cooperação dessas mulheres do Vale que fazem as noivas de barro serem tão fortes. Além de Deuzani e Zezinha, entrevistei Rita, cunhada de Deuzani, que também faz parte do Programa Turismo Solidário que hospeda pessoas em casa. 


\section{Rita}

A ceramista Rita Gomes Ferreira é uma das lideranças entre as ceramistas da localidade, pois articula as outras mulheres da região para que mostrem as suas peças e vendam sua obra na associação. Separada do marido desde que o filho era pequeno, Rita é ex-professora da escola local e vive da verba da cerâmica. Ela se lembra de sua origem:

[...] meu pai e minha mãe nasceram aqui mesmo na comunidade. Eu, apesar de ter morado um tempo fora, voltei para cá e hoje moro aqui com meu filho. Não sou casada. Eu fui. Mas, aí me separei. Tenho só um filho. Ele não trabalha com a cerâmica. Hoje, não. Quando pequeno começou, mas aí não quis continuar. (Rita Gomes Ferreira, 2016).

Diferente das mulheres da região, o marido de Rita não era migrante, pois morava em Belo Horizonte (MG) quando a conheceu. E moraram lá juntos depois de casados. Ela lembra que foi muito difícil criar seu filho sozinha, cuidar da casa, da lavoura, sem o companheiro. A casa de Rita em Coqueiro Campo é uma casa nova, com muro e ao fundo destaca-se a floresta de eucaliptos que domina a paisagem do lugarejo. A casa tem uma varanda na frente e uma cozinha nos fundos, fazendo a relaçáo entre exterior e interior. Ao lado, tem uma garagem. No fundo, saindo da cozinha que dá para a parte externa, situa-se uma área/atelier, onde Rita trabalha, um quartinho e o seu forno.

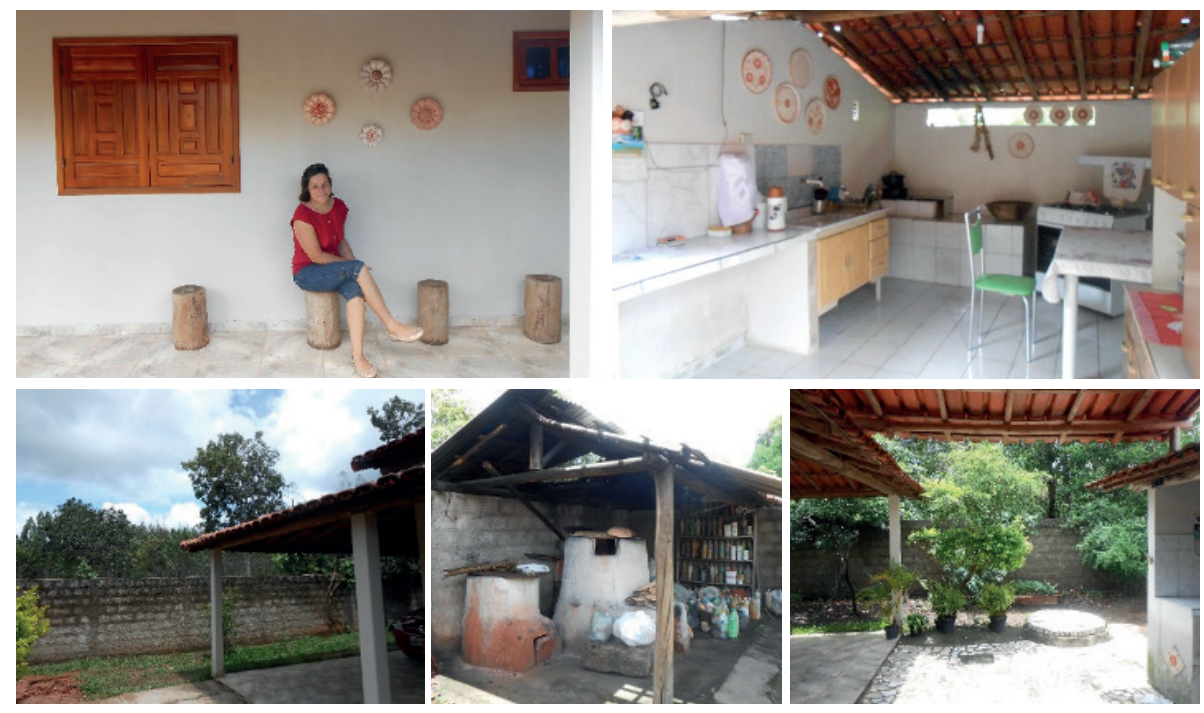

Imagens de 47 a 51 - Casa de Rita em Coqueiro Campo, Minas Gerais, 2016. Fonte: Acervo do autor. 
Ao lado do forno, tem uma estante com os tipos de barros, de cada cor, guardados dentro das garrafas PET. Tudo cercado pela paisagem de eucaliptos. Rita explica como produz suas peças:

[...] como eu disse, eu tenho forno. Para modelar, eu tenho uma mesa que eu coloco aqui mesmo na área e depois que eu termino eu recolho tudo. Eu faço [a cerâmica] aqui mesmo, queimo aqui mesmo, depois que a gente coloca lá na associação. Aí, cada uma faz isso em casa. Normalmente, cada uma tem seu forno. E o barro, a gente pega bastante, divide uma parte para cada uma e cada uma trabalha individualmente. (Rita Gomes Ferreira, 2016).

Rita desenvolve objetos decorativos como jarro de flores, flores de parede, pratos, além de suas bonecas e noivas. Muitas vezes, estas também assumem a forma de moringa para colocar água fresca. Assim como o trabalho das outras ceramistas, as peças de Rita são muito autobiográficas, ou seja, retratam a vida de quem as faz. Percebe-se a semelhança, o rosto. Parece autorretrato mesmo. Com as bonecas, as feiçóes são muito semelhantes. Diz Rita:

[...] eu concordo! $\mathrm{Na}$ verdade, no artesanato a gente representa a vida real daqui. Hoje, apesar das bonecas que são peças decorativas, a gente continua fazendo as peças utilitárias como os potes, as moringas e os pratos. E tem as noivas, acho que o pessoal gosta muito de casar! Primeiro, eu comecei fazendo por uma necessidade financeira. Mas, hoje, eu adoro fazer o artesanato. Uma terapia para mim, sabe? Quando estou trabalhando, a gente entra dentro da história do barro, imagina fazer uma peça e, ali, você esquece das outras coisas. É muito forte. Na verdade, eu começo a trabalhar e esqueço da hora de comer. É, eu gosto muito! (Rita Gomes Ferreira, 2016).

O prazer, e o envolvimento com o trabalho, é expresso por Rita. E inconscientemente as mulheres ceramistas do Vale expressam suas emoçóes e sua realidade no barro, como se tivesse vida. 

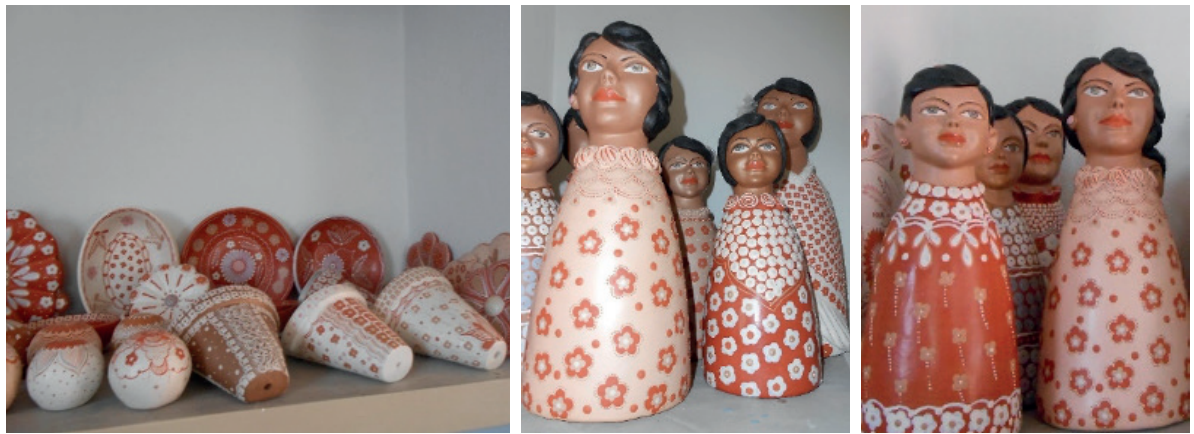

Imagens de 52 a 54 - Vasos, pratos e moringas de cerâmica de Rita na Associação dos Artesãos de Coqueiro Campo, Minas Gerais, 2016 Fonte: Acervo do autor.

Rita cria suas bonecas a partir de um rolinho de barro, de uma espessura fina, que forma um círculo para a base, que depois de pronta vira uma saia com um buraco no meio. A saia é constituída a partir de outros círculos sobrepostos, formando um cilindro com um buraco no meio. Depois do corpo, a artista passa para o tronco e o rosto.
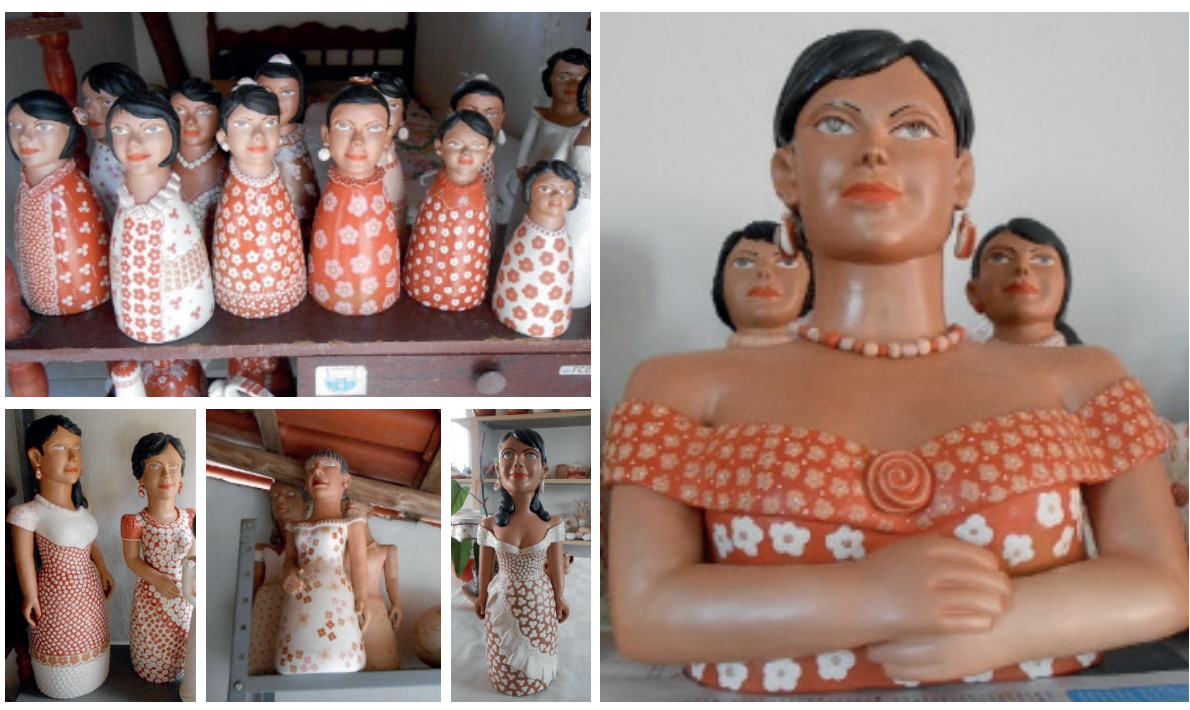

Imagens de 56 e 60, em sentido horário - Moringas e bonecas de cerâmica de Rita em sua casa e expostas na Associação de Artesãos de Coqueiro Campo. Minas Gerais, 2016

Fonte: Acervo do autor. 
Seus vestidos são decorados com flores bem femininas, em diversos modelos diferentes. Os brincos, os colares e os penteados dos cabelos são realizados com esmero e destacam-se na imagem. Os cabelos de suas bonecas são sempre negros como o seu. Rita explica que, entre as bonecas, as noivas sáo as principais peças que produz, mas tem também outras bonecas que faz, como, por exemplo, as mulheres grávidas. Ela conta sobre seu processo de criação: "no artesanato, a gente descobre muitos segredinhos que a gente tem para fazer e cada uma guarda para si. Tem a criação da pintura que é individual, cada uma pinta do seu jeito, sua forma de pintar" (Rita Gomes Ferreira, 2016).


Imagem de 61 a 65, em sentido horário - Noiva-moringa e noivas de Rita em cerâmica, expostas em sua casa, na Associação de Artesãos de Coqueiro Campo e em coleção particular, Minas Gerais, 2016 Fonte: Acervo do autor.

As noivas são o tema mais famoso no Jequitinhonha. Em relação à personalidade das noivas, ela explica qual o nome que daria à noiva: "eu daria o nome de Rita! Rita Guerreira! Brasileira! Nunca desiste!" (Rita Gomes Ferreira, 2016). Apesar de as noivas serem uma marca registrada do Vale e do fato de as ceramistas terem muitas encomendas desse tema, há outras formas ou figuras que ela gosta de explorar na cerâmica: "o artesanato é interessante, porque, normalmente, a gente começa a fazer uma peça e, de repente, no meio, ela se transforma em outra. Nasce um novo e daí a gente vai criando. A gente dá preferência para encomenda. Mas, a encomenda não tira o espaço de criarmos o novo. Não, não" (Rita Gomes Ferreira, 2016).

As noivas de Rita traduzem uma serenidade e harmonia nas expressóes, como a própria personalidade da criadora. Apesar da vida dura, não perde a delicadeza. 
E, apesar de todo trabalho que ela, assim como as outras artesãs, tem que dar conta no dia a dia, ela e as demais ceramistas encontram ainda tempo para o trabalho no barro, que garanta o prazer, a alma de artista e a economia doméstica junto com o dinheiro dos maridos, quando tem um. É como se do barro tirassem sua feminilidade, sua força, sua energia e seu trabalho.

\section{Considerações finais}

No Vale do Jequitinhonha, em Minas Gerais, as artesãs, em sua maioria mulheres, desenvolvem um artesanato exuberante e rico, mesmo com toda a falta de recursos da região. No Vale, concentram-se tendências de criação popular, as ceramistas desenvolvem um repertório variado, mas, apesar de trabalharem com várias peças decorativas, e algumas funcionais, o destaque são as bonecas. Entre as bonecas, o tema, na maior parte das vezes, são as noivas sós e tristes, que são o ícone mais conhecido do Jequitinhonha, designando as mulheres que ficam sozinhas depois que seus maridos migram durante oito meses do ano para trabalhar fora da região. Eles trabalham como operários na construção civil nas grandes capitais, principalmente em São Paulo ou no corte de cana, deixando as propriedades sob os cuidados das mulheres que criam sós seus filhos, daí essas mulheres serem conhecidas como "viúvas de marido vivo".

Essas ceramistas são, como no caso de Rita, ou foram, como no de Zezinha e Deuzani - estas duas hoje mais reconhecidas e independentes -, filiadas na Associação de Artesãos de Coqueiro Campo (AACC), o que mostra o espírito de se organizarem em coletividade das ceramistas da região. Como é frequente na vida dessas mulheres do Vale do Jequitinhonha, as artesãs trabalham na cerâmica e na lavoura. Com o declínio da agricultura de subsistência, que começou a perder espaço para a monocultura de eucalipto na década de 1970, o artesanato em cerâmica ganhou importância econômica e cultural na região. Essas mulheres encontram nessa atividade uma forma de sobrevivência e de afirmação social.

$\mathrm{O}$ artesanato, além de uma prática cultural das populaçóes tradicionais, como se observa no trabalho dessas ceramistas, tem se colocado, cada vez mais, como uma alternativa de renda para quem o produz. A valorização e a demanda cada vez maior de tais peças da cerâmica do Vale pelo turismo vêm proporcionando algumas transformaçóes desde a produção do artesanato até o modo de vida da população na região. O Vale do Jequitinhonha compreende uma riqueza social, cultural e humana que pode ser observada no modo de vida tradicional das comunidades de Coqueiro Campo e de Campo Buriti, como nas obras de Zezinha, Deuzani e Rita, que, mesmo em meio à seca e às dificuldades 
econômicas do lugar, desenvolvem uma série de alternativas de manutenção e reprodução social.

Seus trabalhos são reconhecidos no Brasil e no exterior. Mostram que o fazer artístico e o prazer funcionam como resistência à miséria e às suas vicissitudes. Apesar de a tradição ser passada de máe para filha, a continuidade desse trabalho está ameaçada, pois muitas jovens preferem sair da região em busca de melhores condiçóes de vida. Quando a solidariedade de tipo tradicional se esvai, aquela passada de geração em geração, a sobrevivência da cerâmica fica comprometida e a memória se perde.

\section{Referências}

FROTA, Lélia Coelho. Pequeno dicionário da arte do povo brasileiro, século XX. Rio de Janeiro: Aeroplano, 2005.

NAME, Daniela. Espelho do Brasil: A arte popular vista por seus criadores. Rio de Janeiro: Casa da Palavra, 2008.

\section{Fontes Orais}

FERREIRA, Rita Gomes [57 anos]. [jan. 2016]. Entrevistadora: Gianne Chagastelles. Coqueiro Campo, MG, 29 jan. 2016.

SANTOS, Deuzani Gomes dos [51 anos]. [jan. 2016]. Entrevistadora: Gianne Chagastelles. Coqueiro Campo, MG, 29 jan. 2016.

SILVA, Maria José Gomes da [48 anos]. [jan. 2016]. Entrevistadora: Gianne Chagastelles. Campo Buriti, MG, 29 jan. 2016.

Resumo: Este texto apresenta o trabalho das ceramistas do Vale do Jequitinhonha, em Minas Gerais, cuja história é contada a partir das vozes dessas artesãs. Optou-se pelo uso da História Oral, enquanto referencial teórico-metodológico, problematizando o trabalho, a produçáo artística regional, a tradição oral e as formas de representaçôes culturais e simbólicas. Este ensaio discorre sobre o perfil dessas ceramistas e suas criaçóes, que se originam do barro, e sobre a influência da atividade da cerâmica na cultura, no dia a dia e na vida dos moradores da regiáo do Vale. Desse modo, investiga-se o processo de trabalho das ceramistas, suas biografias, suas relaçóes com a natureza, através da cultura popular produzida por essas artistas. Como ponto de referência, escolheu-se uma regiáo tão rica pela sua cerâmica quanto o Vale do Jequitinhonha, cujo caráter, por assim dizer, sintetizador, explica a riqueza do material e favorece a investigaçáo. 
Palavras-chave: Trabalho. Atividade da cerâmica. Artesãs. Cultura popular. Vale do Jequitinhonha.

The work of the women from Jequitinhonha: the ceramic activity of the widows of a living husband.

\begin{abstract}
This text presents the work of ceramists from Vale do Jequitinhonha, in Minas Gerais, whose life stories is built from the voices of these artisans. We opted for the use of Oral History as a theoretical-methodological framework, problematizing the work, the regional artistic production, the oral tradition and the forms of cultural and symbolic representations. This essay discusses the profile of these ceramists and their creations, which are made from clay, and the influence of the ceramics activity in the culture, in the daily life and in the lives of the residents of the Vale region. In this way, we investigate the ceramist's working process of the potters, their biographies and their relations with nature through the popular culture produced by these artists. As a point of reference, we chose a region as rich in ceramics as the Jequitinhonha Valley, whose synthesizing character explains the richness of the material and benefits the research.
\end{abstract}

Keywords: Work. Ceramic activity. Artisans. Popular culture. Jequitinhonha Valley.

Recebido em 27/05/20

Aprovado em 03/11/20 